\title{
RELIGIOUS CULTURE OF SHARIA MICROFINANCE INSTITUTIONS IN DENPASAR-BALI
}

\author{
Siswanto and Khairil Anwar \\ Faculty of Economics Universitas Islam Negeri \\ Maulana Malik Ibrahim Malang \\ Email: siswanto@pbs.uin-malang.ac.id
}

\section{Abstract}

This study aims to develop organizational culture in Islamic microfinance institutions Baitul Maal wa at-Tamwil (BMT) Sidogiri in Denpasar, Bali. Organizational culture is a basic assumption that grows from social construction results based on a mutual agreement to solve problems and achieve organizational goals. Therefore, the organizational culture in each company is different. This study uses a qualitative approach to data collection and analysis. Data collection uses in-depth interviews with the informant. The informants are leaders, employees, and customers of the BMT. The results of the study show the practice of religious culture. The dimensions of religious culture are amanah or trustworthy, mutual help (ta'awun), kinship and togetherness. Its value is clarified with sharia enterprise theory. This research has implications for developing the concept of organizational culture based on the peculiarities of Islamic microfinance institutions based on pesantren.

Penelitian ini memiliki tujuan untuk mengembangkan konsep budaya organisasi di lembaga keuangan mikro syariah BMT Sidogiri Denpasar, Bali. Budaya organisasi merupakan asumsi dasar yang tumbuh dari hasil konstruksi sosial berdasarkan kesepakatan bersama untuk menyelesaikan masalah dan mencapai tujuan organisasi. Oleh karena itu, budaya organisasi dalam setiap perusahaan berbeda-beda. Penelitian ini menggunakan pendekatan kualitatif dalam pengumpulan dan analisis data. Pengumpulan data menggunakan wawancara

el Harakah Jurnal Budaya Islam Vol. 22 No. 2 Tahun 2020 
mendalam kepada informan. Para informan adalah pimpinan, karyawan, dan nasabah BMT Sidogiri. Hasil penelitian menemukan penerapan budaya religius. Dimensi budaya religius tersebut meliputi amanah, tolong menolong (ta'awun), kekeluargaan $\mathfrak{E}$ kebersamaan. Nilai budaya religius tersebut selanjutnya diperjelas dengan teori usaha syariah. Penelitian ini memiliki implikasi pada pengembangan konsep budaya organisasi berdasarkan kekhasan lembaga keuangan mikro syariah berbasis pesantren.

Keywords: amanah; religious culture; ta'awun; togetherness

\section{Introduction}

Organizational culture plays an essential role in the company. It impacts changes in the structure, strategist organization, and it can even occur a change in the overall organization (Bate, 2010; Napitupulu, 2018; Dubey et al., 2019; Ismayana \& Adeleke, 2020). The study of organizational culture is critical because of its implications for organizations. It also can improve the progress and effective organizations, both within short and periodically relatively long time (Kotter \& Heskett, 2006; Meng \& Berger, 2019). Besides, it positively influences organizational competitive advantage (Swalhah, 2014; Sadri \& Lees, 2001; Aureli et al., 2019). This advantage can be achieved by applying a culture that -oriented customers, shareholders, and employees and managerial leadership at all levels (Singh et al., 2019). Furthermore, it can foster organization trust by noting task-oriented culture, support-oriented culture, achievement-oriented culture, and power-oriented culture (Alizadeh \& Panahi, 2013).

Cultural organizations are also able to increase the motivation of the implications for the performance of the company (Hakim, 2012; Rivai et al., 2019; Daud, 2020), the performance of the employee (Rosyidi, 2013; Rivai et al., 2019; Dewi \& Wibow, 2020), and creating employee satisfaction (Angel, 2015; Simovic \& Perovic, 2020; Mesfin et al., 2020). It can shape the image of the organization (Sunuantari, 2012; Balaji et al., 2020). The organizational culture containing values, beliefs, and assumptions coherent with an adhocracy culture can be a determinant for increasing product innovation (Valencia et al., 2010; Naranjo-Valencia et al., 2019).

The concept of ethics in Islamic organizational culture aims to protect and contribute to the community as the external environment (Beekun, 2004). An organization has social responsibility in three aspects: (1) the actors 
organization, (2) the natural environment, and (3) the social welfare in general. The application of ethical concepts in Islamic organizations' culture is a value that can sometimes distinguish with non-Islamic organizations (conventional). Culture organization is the result of social construction agreed collectively in an organization. Therefore, each organization has the organizational cultural characteristics that distinguish it from other organizations (Bangun, 2008; Siswanto, 2018). In a specific context, conventional financial institutions that have a profit-oriented orientation will construct an organizational culture supporting the achievement. It can negate the possibility for non-Islamic organizations (conventional) to undertake actions having epistemological value in contributing to society and carry out social responsibility. The basic concept of organization built on non-Islamic organizations and Islamic organizations has fundamental differences.

Institutions finance can be classified into two, namely banks and non-banks. Based on its legal principles, institutions finance in Indonesia differentiated into two, namely conventional and Islamic. Islamic Financial Institutions are implemented by applying Islamic principles that refer to Islamic business ethics based on the Qur'an and As-Sunnah (Juliyani, 2016). Baitul Mal Wa at-Tamwil (BMT) is a type of financial institution micro sharia non-banks. This Islamic microfinance institution has an orientation towards increasing the welfare of members. The existence of BMT has an essential role in developing the economy in Indonesia, especially in the micro-business sectorsmall and medium enterprises (SMEs). BMT's presence is expected to be a mediating instrument for channelling community funds to micro, small and medium enterprises based on the principle of ease and free usury. It also improves the standard of living of small and medium level communities. One of the BMTs carrying out the objectives described above is the BMT Sidogiri

The BMT Sidogiri is one of the cooperatives that has developed quite rapidly in Indonesia. As a Sharia non-bank financial institution, it turns out that the BMT can also develop rapidly in areas where the majority of the population is non-Muslim. The Finance Director, said that it becomes a concrete example of BMT's development in the community with the majority of people arenon-Muslims. Even to date, there are seven branches in Bali, namely Denpasar, Melaya, Negara, Seririt, Gianyar, Singaraja, and Badung. 


\section{Organizational culture and the context of Sharia enterprise theory}

Organizational culture is a basic assumption that can be learned and used in solving problems faced in the form of adjustment to the external environment and internal integration (Schein, 2010). In achieving a goal, each organization has a unique culture. It can be a critical instrument in an organization to realize the achievement of organizational goals (Kotter \& Heskett, 2006). Organization culture has two components, namely the guiding beliefs and daily beliefs.

Guiding beliefs grew into the philosophical organization values (Davis, 1984; Sobirin, 2007). These values then become guidelines used to deal with external self-adaptation and internal self-integration (Schein, 2010). While daily beliefs are the operational or device values practically implemented in real life (Collin \& Porras, 2001). If guiding beliefs have become values practised in the daily life of an organization, then the organization will be healthier, even able to dominate behaviour and influence the implementation of the organization's strategy. Organizational culture has three characteristics: (1) it is given to new employees through the process of socialization, (2) it influences the employee's behaviour or actions in the workplace, and (3) it applies to the outside view and the ability to resist to change (Kreitner \& Kinicki, 2014).

Current studies concern on organization culture. The dimensions of organizational culture will increase competitive advantage in the Jordanian Hospital (Swalhah, 2014). A positive culture in an organization can foster significant competitive advantage (Sadri \& Lees, 2001; Aureli et al., 2019). Not only that, but organizational culture also has an impact on productivity, morale, employee behaviour, and in turn, can also increase profitability. This study clicks the eloped concept of organizational culture. The company becomes popular, defining the corporate culture, showing the impact on real organizations; both positively and negatively, and consider how culture change can be done.

Organizational culture can increase organizational trust (Alizadeh \& Panahi, 2013; Meng \& Berger, 2019). In this case, maintaining the organization's culture can enhance confidence in the organization. The dimensions used are task-oriented, support-oriented, achievement-oriented, and power-oriented cultures. The findings at Bank Mu'amalat in Central Java indicate no relationship between the dimensions of organizational culture and beliefs. Organizational culture can also increase employee's 
work motivation (Hakim, 2012). It can also increase product innovation (Valencia et al., 2010; Naranjo-Valencia et al., 2019). The study indicates that organizational culture is one of the elements in enhancing and inhibiting innovation. Adhocracy culture can improve service innovation and product development. Therefore bureaucratic culture can inhibit product innovation.

These findings demonstrate how organizational culture has positive implications for the organization. However, each organization has a different culture. The organization is a collection of people to achieve goals. Since organisms have different values; organizations also have different values and goals (Triyuwono, 2000). Sharia organizations have the goal of achieving material and non-material welfare (Triyuwono, 2001). This organization is a means used by humans to carry out their duties as khalifatulloh fil ardh. This is certainly different from other organizational concepts. Modern organizations are often profit-oriented with entity theory (Kam, 1990; Triyuwono, 2001). Therefore, understanding sharia organizations need to incorporate sharia organization theory. This research uses sharia enterprise theory to understand the organizational culture in the sharia microfinance institutions of BMT Sidogiri.

Culture is the complexity of the overall, including knowledge, belief, art, morals, law, custom, and capability more and habits of whatever possessed by humans as part of society (Sobirin, 2007). It also has broad meaning, relating to tangible things as well as beliefs in ideas and habits. Another definition of culture refers to various rules for life society, the ideas of early man's work, beliefs and human habits (Malinowski, 1936). It is associated with human life in general, but it began to be associated with human life as classified by groups.

This shift in understanding can be reviewed based on cultural meaning as a framework of thinking that explains beliefs, behaviour, knowledge, agreements, values, goals all of which make up the outlook on life a group of people (Sobirin, 2007). The function of culture, in general, is challenging to distinguish from the function of group culture or organizational culture, because the culture is a social phenomenon (Taliziduhu, 2003). A cultural function has intended an identity, a source of inspiration, pride, and resources, value acculturation, pattern behaviour, as in the form of consistency someone in the act. Meanwhile, the organization is a group of people who work together to achieve a common goal (Sobirin, 2007). This definition explicitly shows the organization's fundamental essence, namely the group of people and common goals. It involves members who cooperated and coordinated, having a pattern 
of structured work, and was set to achieve a common goal or a set of goals previously agreed upon (Robbins \& Judge, 2017).

Organization culture regarding patterns of belief that results in the values and shapes individual's behaviour within the organization. It is also a pattern of basic assumptions used by a group to deal with problems, adjust to the organization's external environment, and integrate with the internal environment (Schein, 2010). Furthermore, the basic assumptions involve concepts which form the basis of finding and solving life's problems. This basic assumption can be in the form of a belief, awareness, thoughts, feelings that are the source of values and actions. According to Schein (2010), culture as beliefs and values is a justification that is embraced and something that can be debated.

Islamic organizational culture is a paradigm based on the Koran and Sunna shaping people's values and behaviour in an organization. The dogmatic Islamic paradigm demands a moral obligation for humans to implement all the Sharia rules in all aspects of life, including culture in an organization. Islamic organizational culture is part of the Islamic economy, which is also inseparable from Islamic concepts (sharia) in this regard.

Organizational culture is based on one of its functions, namely, an identity that distinguishes an organization from other organizations. The identity intended in this case is a characteristic possessed by every organization. Islamic organizational culture has specific characteristics, namely: to believe in Allah, work hard, be honest, emphasize morality, make consultative decisions, maintain good behaviour and abandon the bad practice bad (Hoque et al., 2018).

Organizational culture has three levels or elements covering artefacts, values, and basic assumptions. They are the result of social construction agreed collectively in an organization (Schein, 2010). The foundation of work culture in Islam refers to the basic concept, which is the basis of Islamic economics and can also be based on an Islamic organization's culture comprising faith (monotheism), leadership (khilafah) and justice (al'adalah) (Hakim, 2012).

The concept of monotheism (faith) is a monotheistic trust in Allah SWT as the creator of and regulator of all natural entities universe. Based on that, humans as part of the entity must have absolute obedience which in the context of organizational culture can be implemented in all forms of actions that are ethical and worthy of worship. Monotheism (faith) in organizational culture is a basic concept that distinguishes an Islamic organization from 
a non-Islamic (conventional) organization. The concept of khalifatullah fil ardh shows that humans are manifestations of the function of Allah SWT on earth as managers and regulators. It requires humans to carry out their functions following the teachings in Islam, because humans will ultimately be held accountable as representatives of Allah SWT on earth. The concept of justice (al'adalah), namely demanding humans in working must be following the teachings of sharia and not based on the vanity in the pursuit of profit. Business in conventional rules that tend to be capitalists allows others' vanity and tyranny to get the maximum profit. Based on that, the meaning of fair in sharia view includes no cheating, lying, breaking promises and others.

Another feature of Islamic organizational culture is in the principle that working is part of worship, oriented to benefits, optimizing ability, with full of confidence and optimism, requiring an attitude of tawazun (balance), paying attention to the halal element and avoid the unclean element (Hakim, 2012). It also views that organizations or companies are like living human beings. Human being has both material and non-material needs (Triyuwono, 2000). Conventional organizations have an orientation toward meeting material needs. This orientation is different from Sharia based organizations. Sariah-based organizations have an orientation to meet material and non-material needs. The process of fulfilling physical and spiritual needs can be carried out by implementing an organizational culture. A theory can be applied in Shariabased institutions or organizations, namely Sharia Enterprise Theory (SET).

Sharia enterprise theory is a theory that makes God as central to everything (Triyuwono, 2006). Humans and the universe will return to God. Humans are sent to this earth only as God's representatives and must obey all the laws set by God. The theory places God as the highest stakeholder in an organization (Kalbarini, 2018). By placing God as the highest stakeholder in an organization, the organization's activities, behaviours, values, and basic assumptions are centred on Him. An organization can be said as a sharia organization if the organization can create an organizational culture by placing God at the centre of everything.

The application of the Sharia Enterprise Theory (SET) concept involves two parties, namely, direct and indirect participants (Triyuwono, 2006). A direct participant is a group that has a direct relationship with the business in an organization. Whereas the indirect participant has no connection with a company's business. The concept of SET provides a valuable lesson: the ultimate nature of ownership is in God's power. At the same time, humans 
are only entitled to manage (khalifatullah fil ardh). It is based on Qs. Al-An'am: 165, meaning: "And it is He who has made you successors upon the earth and has raised some of you above others in degrees [of rank] that He may try you through what He has given you..." (Qur'an 6: 165) .

\section{Methods}

The site of this research is BMT Sidogiri Denpasar, Bali. The reason for choosing the research site is the distinction of social constructs in most Denpasar-Bali non-Muslim communities with other branch locations. The research method uses a qualitative approach with case study design to understand contemporary studies; in this context, organizational culture in Islamic microfinance institutions (Yin, 2017). The selection of this research method is intended to find out in detail related to Islamic organizations' culture in the BMT. It can be obtained using qualitative analysis methods based on observations, interviews, and document reviews (Moleong, 2010).

Key informants provide information to research to collect data and provide recommendations for further informants (Creswell \& Poth, 2016). They are the leaders of the BMT. Meanwhile, other informants are employees and customers as the organization's external informants. This study focuses on developing the concept of Islamic organizational culture found in the BMT. The data collected based on interviews with several informants selected based on the length of work, which is expected to have more experience and provide the necessary data related to the culture of Islamic organizations.

\section{Results and Discussion}

\section{Characteristics of Religious Culture of Microfinance Institutions}

In the world of competition, every company has its strategy used to create competitive advantage. To create competitive strategies, companies can improve asset is not visible (intangible) on the company and organizational culture. Organizational culture is an asset did not look plays somewhat important implications in increasing assets are visible, it can improve the performance of the company in the long term and be an instrument is essential in an organization as an attempt to realizing the achievement of organizational goals (Kotter \& Heskett, 2006).

Organizational culture is a basic assumption that grows from social construction results in a company that is built based on mutual agreement 
and is used as an instrument for achieving goals and solving problems that arise. Therefore the application of organizational culture in every company is different, both Islamic and conventional organizational culture. Even BMT Sidogiri Denpasar also has an organizational culture different from other Islamic organizations. The culture based on its function in an organization is an identity that distinguishes an organization from other organizations.

The characteristic of Islamic organizational culture in BMT Sidogiri involves the culture of religiosity. This is based on the results of interviews conducted with Bashori Alwi as the Head of Savings and Loans (KBS):

"The pesantren's religious culture is still maintained, such as praying in congregation at the office, praying together before work, then there is a joint meeting usually every week, and pilgrimages to the Auliya maqbarah in the Bali area are scheduled once a month. The same is the agenda of the Koran of the book of Ihya' Ulumuddin and Fathul Mu'in. Actually, the IAS (Sidogiri Alumni Association) event but employees are required to take part in the event usually every two months."

Also, Syamsul as AOSP issued a statement related to religious culture in the BMT:

"As an Islamic organization, certainly the first one built is religious culture. Before the opening that morning, we cultivated prayers together in the office before starting our work, especially for the Fatihah, usually to the masyaikh, yes for the jammed members too, so the point is for the progress of the BMT. If in Islamic terms it is called tawakkal, before it will only endeavour or hard work."

In practice, organizational culture cannot always be carried out properly. Several obstacles arise that hinder the application of culture in organizations. Like the obstacles encountered in carrying out the Islamic organizational culture in the BMT. The constraints cover the difficulty to build public confidence in BMT Sidogiri.

\section{Amanah}

Another culture of BMT UGT Sidogiri is Amanah. The employees stated that developing the organization was a form of trust from God to act more professionally (Siswanto, 2019). Their motives for action are not intended to fulfil their desires, but as a form of trust and worship to God, which is a reflection of religious motives, based on an interview with Bashori:

"To gain the trust of the community, we must have an amanah attitude, besides we also always try to be honest. Because automatically, when we are honest, public trust will also be built. For example, when employees are asked about savings and deposit products at BMT Denpasar Branch, they explain in detail related to the product's advantages and disadvantages of the product."

Religious culture in the form of the mandate character is the key to the 
success of the BMT. Although they are a minority, BMT Sidogiri is trusted by the Balinese. Mandate culture has an essential role in fostering community trust in saving at BMT Sidogiri, as stated Fuad:

"The key is the amanah if it is not amanah, how can people want to put their money in BMT. Often the member who usually saves the money puts the same savings account on the window or the electricity meter sometimes. It is just the AO just take it already recorded already, so believe the community."

The employees are pesantren alumni. Even though they have never formally studied economics when they were students, the BMT can run smoothly with the culture of trust. M. Ali stated that the main capital in developing the UGT Denpasar BMT was trustworthiness.

The santri life attitude is a reflection of the pesantren's outlook on life. Since entering the boarding school environment, a santri feels like entering a different world. The primary doctrine in pesantren views the totality of life as worship. The doctrine firmly planted in the santri shapes the character and outlook of life which is oriented towards ukhrowi life. This perspective holds on until graduating and becoming alumni. Such a view affects the way of looking at worldly life, not everything so that the santri life outlook is far from the greedy and materialistic view of life (Siswanto, 2019).

Ta'awun

This Islamic microfinance institution has a pesantren culture because all BMT employees are pesantren alumni who have secure emotional connections. They work based on mutual assistance or ta'awun. The dimension of religious culture which is tangible to help each other.

Life as santri is firmly attached to the character of alumni. Religious values have been integrated into everyday life, as the value of mutual assistance or ta'awun in Arabic. Islamic boarding schools are social institutions that can construct students' character and internalize religious values through integral education systems (Syam, 2009). Pesantren transforms and internalizes religious culture, one of which is the culture of mutual assistance. This dimension of religious culture is an implementation of the QS Al- Maidah: 2, meaning; "... And cooperate in righteousness and piety, but do not cooperate in sin and aggression. And fear of Allah; indeed, Allah is severe in penalty."

The employees have an awareness to help each other. When there is one employee who has a family problem causing less focus on working, it may result in an error in the calculation. When it happens, other employees try to help finding solutions. This was also stated by Bashori Alwi, that the 
characteristic of helping each other becomes a distinguishing feature in the religious culture of BMT UGT Denpasar. Besides, organizational culture can also play a role in solving organizational problems by adjusting internal and external environments (Schein, 2010).

\section{Togetherness and kinship}

The culture of togetherness and kinship is the cultural dimension of the religious organization at the BMT. Relationships between employees are like family. They have an emotional connection as the alumni of Pesantren Sidogiri Pasuruan. They also realize that BMT members and customers are part of a large BMT family. Togetherness and family relationships contribute to the work effectiveness. The achievement of the BMT is one of the implications of good internal relations. A sense of brotherhood among workers is the key to their success. Even though there are internal problems, they can solve immediately because of this family relationship. Fuad stated this:

"My experience in handling several existing offices, most of which are developing rapidly, when the internal office is strong. So indeed this internal office must be strengthened first with a family culture. We are here as brothers. It's not that we don't have internal problems, there are problems, they don't drag on."

\section{The Meaning of Religiosity in Sharia Enterprise Theory}

The meaning of the word "religious" according to the Indonesian Dictionary $(\mathrm{KBBI})$ is anything that is religious or has something to do with religion. The religious culture is social construction agreed together into a habit of religion or religious nature. It is created from continuous habituation to raise awareness to carry out the culture (Mulyadi, 2018; Fathurrohman, 2015). This culture becomes an identity that distinguishes between faithbased organizations and conventional organizations that are materialistic and secular. In the BMT, its practice includes; amanah or trustworthy, ta'awun, and togetherness.

Religiosity also has the meaning of carrying out Islamic values with totality (Rusdiyanto, 2019). The essence of a Muslim's actions is monotheism or God's reverence. In the Islamic microfinance institution, it maintains the culture of religious organizations even though they are in a minority environment. Based on Islam's perspective, humans and their social environment are a unity, united in the oneness of Allah (monotheism). Both are God's creatures, and both have interdependent relationships (Ba-Yunus, 1988). 
Islamic microfinance institutions are based on sharia principles and make God their final destination. These characteristics are in harmony with the sharia enterprise theory. Sharia entrepreneurship theory is a theory for companies that have combined their activities with spiritual values (Wahyuni, 2013). Meanwhile, God's position is the centre of everything in sharia entrepreneurship theory (Triyuwono, 2006). The theory places God as the highest stakeholder in an organization (Kalbarini, 2018). Therefore the activities, behaviours, values, and underlying assumptions in the organization are centred on Him. The organization of sharia puts God at the centre of everything and creates an organizational culture based on the principle of religiosity.

Humans have a "amanah" as khalifatullah fil ardh, namely God's representative on earth. They are responsible for arranging the earth following religious values. Sharia Enterprise theory explains that the organization has the highest stakeholder, God. Besides, the nature of the ultimate owner of the universe, including organization, is God. It implies that the organizations that have these characteristics are metaphorical with the mandate metaphor. That is organizations that have humanist, emancipatory, transcendental and teleological characteristics (Triyuwono, 2001). Some cultures at the level of artefacts include praying in congregation, joint prayers before work, joint prayers held every week, pilgrimage to the Mauliyah Auliya' in Bali is held once a month, reciting the Ihya' 'Ulumuddin and Fathul Mu' in books which are held every two months.

The religious culture is useful to maintain its existence as an Islamic financial institution. The practice of joint prayer, istighotsah, and pilgrimage to the Auliya maqbarah is a form of tawassul to caregivers (masyayikhs) of the Sidogiri boarding school and the guardians of God to obtain blessing and fluency in work. However, there is also a unique feature in the BMT, which is tawasul sending fatihah to caregivers of Sidogiri pesantren and trustees and all members or customers, especially customers who experience bad loans. Besides, there is also a study of the book of Ihya "Ulumuddin and Fathul Mu'in which are Sufism studies that must be attended by all the employees. It aims to foster a Sufi mentality to all employees to work well and avoid the disgraceful behaviours.

Religious culture can also create effective employee performance. That is because the existence of religious values in work will create peace for employees to focus on working. In Islam increasing the value of religiosity by always remembering Allah will be able to make peace of mind, as mentioned 
in QS Ar-Raad: 28, meaning; "Those who have believed and whose hearts are assured by the remembrance of God. Unquestionably, by the remembrance of God hearts are assured." Religious culture also has values of obedience and human submission as creatures of God. In work, people are encouraged to work hard and pray to God for good results.

\section{Amanah: Reflections on Khalifatullah fil Ardh}

Humans have "amanah" as khalifatullah fil ardh based on QS Al-Baqarah: 30 (Triyuwono, 2001). With this amanah, humans have to take action based on the trustee, namely Allah SWT. Meanwhile, the amanah, in this case, is to manage the earth, including the organization, with full responsibility (Rahardjo, 1995). The attitude of amanah is always based on words, beliefs, and actions based on the truth of reality. There are no deliberate contradictions and conflicts between words and deeds. This can be interpreted that what is said to be honest is the truth of the spoken word, more transparency, and there is no element of data manipulation and misuse of information. Amanah means always prioritizing the truth of the information provided. Also, when they calculate members' savings, it is honestly related to the nominal, and when there is excess money, it is returned to the members. This is an effort to grow and maintain the trust of members of the BMT.

Amanah means trustworthy, responsible and credible. It can also mean the desire to fulfil something under the provisions. It belongs to every Muslim's obligation who will determine a person's good morals in relationships every day (Shuhari et al., 2019). Among the values associated with honesty and completing it is trustworthy. The consequence of the mandate is to return every right to its owner, whether a little or a lot, does not take more than he has, and does not reduce others' rights. In Islam, Allah commands believers to be honest (right) and encouraged to create an honest (right) environment. Allah stated this in the Qur'an surah At-Taubah: 119, meaning; "O you who have believed, fear God and be with those who are true". Trustworthy means to carry something given and full responsibility.

Sharia enterprise theory is a theory that makes God as centre of everything (Triyuwono, 2006). God created man with a purpose and purpose. Allah made man as khalifatullah fil ardh or God's representative on earth. This is the "mandate" from Allah to humans. Humans' task is to manage all of God's creations and creations, including the means to an end, and including the organization. All mandates will be held accountable to the Owner of Power. 
Man is obliged to account for all activities or activities to God, because humans are His representatives on earth. Meanwhile, humans are responsible for their fellow environment and the environment as a manifestation of social creatures interacting with fellow humans in the universe.

\section{Ta'awun: The level of culture based on sharia enterprise theory}

As social beings, humans naturally live in interrelation and need one another, both within the scope of the broader social environment and within the social sphere of an organization. The culture of mutual assistance ( $t a^{\prime}$ awun) has a decisive role in creating solidarity between employees. Likewise, a culture of mutual assistance negates the tendency for harmful competition between employees based on envy and hatred. The culture of helping each other can be seen from employees' behaviour towards other employees who are experiencing disasters or problems.

Helping others is God's command. Mutual help is help in kindness and the context of submission to Allah. Allah Almighty commands it in Qs.5:2, which means; ... And cooperate in righteousness and piety, but do not cooperate in sin and aggression. Islam forbids doing help in matters of sleaze, sin, and haram. The concept of Sharia Enterprise Theory explains that the ultimate nature of ownership is in God's power, while humans only have the right to manage (Triyuwono, 2000). Management of the organization based on the provisions of the primary owner. God rules the right man for mutual help in goodness and piety. The organization has a goal to achieve the welfare of stakeholders which includes the internal and external environment.

Helping with the internal environment is reflected in helping each other employees who get into trouble. Meanwhile, the external environment is reflected in excellent service to customers and the environment in need. There is a BMT UGT social responsibility program providing compensation and alms to the surrounding environment. This is a cultural reflection, mutual help. God, humans, and the environment are organizational stakeholders based on sharia entrepreneurship theory (Yulianto \& Solikhah, 2016). These stakeholders have a direct contribution to the organization. Stakeholders who directly contribute to the organization are called direct stakeholders, which consist of employees and customers. Meanwhile, the stakeholder perspective is the environment around Islamic microfinance institutions that indirectly make financial and non-financial contributions (Novarela \& Sari, 2015). 


\section{Togetherness \& Kinship: Symbols of Religious Culture}

Religious culture has several different aspects between one religion and another, especially in individualism and togetherness or collectivism (Cohen \& Hill, 2007). Judaism has a prominent aspect of collectivism and biological descent. In contrast, the Protestant Religion is more focused on personal beliefs. Communities with a religious culture show a high level of togetherness compared to secular communities (Sagy et al., 1999). Togetherness is one of the characteristics of pesantren life. Aside from being one of the triggers for social cohesion, pesantren teaches students about the value of obedience, sincerity, solidarity, togetherness, equality, mutual help, simplicity (Saihu \& Rohman, 2019). One of the activities of the BMT to establish togetherness is to carry out "major" activities.

The organization is a collection of some people who have a purpose. An organization sometimes has a susceptibility to differences in perceptions and disputes. This can have a negative tendency on overall organizational performance. Therefore, the culture of togetherness and kinship at BMT Sidogiri is essential to create a harmonious and harmonious atmosphere. A culture of togetherness and good family relations between employees will improve effective performance that has a positive impact on overall organizational performance. In fact, a culture of togetherness and good family with members will increase the loyalty of members towards the BMT.

The culture of togetherness and kinship was formed with the agenda and routines carried out. This can be seen from the routine badminton sports held every week. Besides, they have shared meals held once a month at the employee's house in turn. This is an effort made to strengthen internal relations between employees to be like relatives. When there are problems in the internal office, they can be resolved properly and not protracted. Togetherness and kinship in Islam is clearly highly recommended and forbids Muslims to divorce and experience division (Qs. 3: 103) .

\section{Conclusion}

This study aims to develop the concept of organizational culture based on the characteristics of Islamic microfinance institutions BMT Sidogiri. The organizational culture contributes to improving employee and organizational performance, product innovation, job satisfaction, trust and competitive advantage. Besides, organizational culture has a role distinguish between one organization and others. The organizational culture is unique because it can 
develop pesantren organizations' religious culture, even though they are in a non-Muslim environment. The religious culture contributed to the increase in assets and turnover of the BMT.

BMT Sidogiri cultural characteristics are religious culture. Management and employees of the BMT developed the religious culture of social construction through religion or religious customs based on pesantren's values. The religious culture is created from internalizing values, norms, and habituation continuously to bring up an awareness. Their religious culture is shown in three dimensions, namely; trustworthy or amanah, ta'awun, togetherness. Humans have "amanah" as khalifatullah fil ardh. That is, humans take action based on the trustee, namely Allah SWT. The trust attitude is always based on words, beliefs, and actions based on the truth of reality. The truth of the words spoken is more transparent, and there is no element of data manipulation and misuse of information. The amanah culture is reflected in the truth of the information provided. The culture of mutual help(ta'awun) has contributed to creating solidarity and brotherhood among employees. The organization has the goal of increasing the welfare of internal and external environmental stakeholders. Helping the internal environment is shown by helping each other employees. There is a social responsibility program providing compensation and alms to the surrounding environment. This is a reflection of the culture of mutual help. Togetherness is a hallmark of pesantren life. Aside from being one of the triggers for social cohesion, pesantren teaches students about the value of togetherness, helping one another.

\section{References}

Alizadeh, S., \& Panahi, F. 2013. Organizational culture constructs in the development of organizational trust. International Journal of Management Research and Reviews, 3(8), 3238.

Angel, C. 2015. Pengaruh Budaya Perusahaan terhadap Keunggulan Bersaing melalui Kepuasan Karyawan pada Perusahaan Kafe Restoran di Surabaya. Business Accounting Review, 3(1), 280-291.

Aureli, S., Giampaoli, D., Ciambotti, M., \& Bontis, N. 2019. Key factors that improve knowledge-intensive business processes which lead to competitive advantage. Business Process Management Journal 25(1), 126-143. https:// doi.org/10.1108/BPMJ-06-2017-0168

el Harakah Jurnal Budaya Islam Vol. 22 No. 2 Tahun 2020 
Balaji, M. S., Jiang, Y., Singh, G., \& Jha, S. 2020. Letting go or getting back: How organization culture shapes frontline employee response to customer incivility. Journal of Business Research, 111, 1-11.

Bangun, W. 2008. Budaya Organisasi: Dampaknya pada peningkatan daya saing perusahaan. Jurnal Manajemen Maranatha, 8(1), 38-49.

Bate, S. P. 2010. Strategies for cultural change. Routledge.

Ba-Yunus, I. 1988. Contemporary sociology: An Islamic critique. Islam: Source and Purpose of Knowledge Proceedings and Selected Papers of Second Conference on Islamization of Knowledge, 1402.

Cohen, A. B., \& Hill, P. C. 2007. Religion as culture: Religious individualism and collectivism among American Catholics, Jews, and Protestants. Journal of Personality, 75(4), 709-742.

Collin, J. C., \& Porras, J. I. 2001. Built To Last: Tradisi Sukses Perusahaanperusahaan Visioner. Transl. Hifni Alifahmi, Erlangga.

Creswell, J. W., \& Poth, C. N. 2016. Qualitative inquiry and research design: Choosing among five approaches. SAGE.

Daud, I. 2020. The Influence of Organizational Culture and Compensation on Employee Performance with Work Motivation as a Mediating Variable. Reference to This Paper Should Be Made as Follows: Daud, I, 122-128.

Davis, S. M. 1984. Managing corporate culture. HarperCollins.

Dewi, N., \& Wibow, R. 2020. The effect of leadership style, organizational culture and motivation on employee performance. Management Science Letters, 10(9), 2037-2044.

Dubey, R., Gunasekaran, A., Childe, S. J., Roubaud, D., Fosso Wamba, S., Giannakis, M., \& Foropon, C. 2019. Big data analytics and organizational culture complement swift trust and collaborative performance in the humanitarian supply chain. International Journal of Production Economics, 210, 120-136. https://doi.org/10.1016/j.ijpe.2019.01.023

Fathurrohman, M. 2015. Budaya Religius dalam Peningkatan Mutu Pendidikan. Kalimedia. 
Hakim, L. 2012. Membangun Budaya organisasi unggul sebagai upaya meningkatkan kinerja karyawan di era kompetitif. Benefit: Jurnal Manajemen Dan Bisnis, 15(2), 106-123.

Hoque, M. E., Nik, H. N. M. H., \& Azmi, M. H. B. 2018. Moderating effects of marketing communication and financial consideration on customer attitude and intention to purchase Islamic banking products: A conceptual framework. Journal of Islamic Marketing, 9(4), 799-822. https://doi. org/10.1108/JIMA-01-2017-0005

Ismayana, M. P., \& Adeleke, A. Q. 2020. The Influence of Organizational Culture on Construction Risk Management among Kuantan Malaysian Construction Industry: A Partial Least Square Structural Equation Modeling Approach. Social Science and Humanities Journal, 1693-1704.

Juliyani, E. 2016. Etika Bisnis dalam Perspektif Islam. Jurnal Ummul Qura, 7(1), 63-74.

Kalbarini, R. Y. 2018. Implementasi Akuntabilitas dalam Shari'ah Enterprise Theory di Lembaga Bisnis Syari'ah (Studi Kasus: Swalayan Pamella Yogyakarta). Al-Tijary, 4(1), 1-12.

Kam, V. 1990. Accounting theory. Wiley.

Kotter, J. P., \& Heskett, J. L. 2006. Budaya korporat dan Kinerja. Transl.Susi Diah Hardaniati \& Uyung Sulaksana.

Kreitner, R., \& Kinicki, A. 2014. Organizational behavioral. Boston: McGraw-Hill.

Malinowski, B. (1936). Culture as a Determinant of Behavior. The Scientific Monthly, 43(5), 440-449.

Meng, J., \& Berger, B. K. 2019. The impact of organizational culture and leadership performance on PR professionals' job satisfaction: Testing the joint mediating effects of engagement and trust. Public Relations Review, 45(1), 64-75. https://doi.org/10.1016/j.pubrev.2018.11.002

Mesfin, D., Woldie, M., Adamu, A., \& Bekele, F. 2020. Perceived organizational culture and its relationship with job satisfaction in primary hospitals of Jimma zone and Jimma town administration, correlational study. BMC Health Services Research, 20, 1-9. 
Moleong, L. J. 2010. Metodologi Penelitian Kualitatif. Remaja Rosdakarya.

Mulyadi, E. 2018. Strategi Pengembangan Budaya Religius di Madrasah. Jurnal Kependidikan, 6(1), 1-14.

Napitupulu, I. H. 2018. Organizational Culture in Management Accounting Information System: Survey on State-owned Enterprises (SOEs) Indonesia. Global Business Review, 19(3), 556-571. https://doi. org/10.1177/0972150917713842

Naranjo-Valencia, J. C., Jiménez-Jiménez, D., \& Sanz-Valle, R. 2019. Organizational culture effect on innovative orientation. Management Decision, 49(1), 55-72.

Novarela, D., \& Sari, I. M. 2015. Pelaporan Corporate Social Responsibility Perbankan Syariah dalam Perspektif Shariah Enterprise Theory (SET). Jurnal Akuntansi dan Keuangan Islam, 3(2), 145-160.

Rahardjo, M. D. 1995. Khalifah. Ulumul Qur'an Jurnal Ilmu Dan Kebudayaan, 1.

Rivai, R., Gani, M. U., \& Murfat, M. Z. 2019. Organizational Culture and Organizational Climate as a Determinant of Motivation and Teacher Performance. Advances in Social Sciences Research Journal, 6(2), 555-566.

Robbins, S. P., \& Judge, T. A. 2017. Organizational behavior. Pearson.

Rosyidi, S. 2013. Kinerja karyawan ditinjau dari analisis faktor budaya perusahaan. Jurnal Penelitian Psikologi, 4(2).

Rusdiyanto, R. 2019. Upaya Penciptaan Budaya Religius dilingkungan Kampus Universitas Muhammadiyah Jember. TARLIM: Jurnal Pendidikan Agama Islam, 2(1), 43-54.

Sadri, G., \& Lees, B. 2001. Developing corporate culture as a competitive advantage. Journal of Management Development.

Sagy, S., Orr, E., \& Bar-On, D. 1999. Individualism and collectivism in Israeli society: Comparing religious and secular high-school students. Human Relations, 52(3), 327-348.

Saihu, S., \& Rohman, B. 2019. Pembentukan karakter melalui model pendidikan transfromatife learning pada santri di pondok pesantren Nurul Ikhlas Bali. Edukasi Islami: Jurnal Pendidikan Islam, 8(02), 435-452. 
Schein, E. H. 2010. Organizational culture and leadership (Vol. 2). John Wiley $\&$ Sons.

Shuhari, M. H., Hamat, M. F., Basri, M. N. H., Khairuldin, W. M. K. F. W., Wahab, M. R., Alwi, E. A. Z. E., \& Mamat, A. 2019. Concept Of Al-Amanah (Trustworthiness) and Al-Mas'uliyyah (Responsibility) for Human's Character from Ethical Islamic Perspective. Journal of Legal, Ethical and Regulatory Issues, 22, 1-5.

Simovic, O., \& Perovic, D. 2020. How organizational culture influences satisfaction of employees shown on the example of tourism businesses in Montenegro. Interdisciplinary Description of Complex Systems: INDECS, 18(2-B), 222-239.

Singh, S. K., Chen, J., Del Giudice, M., \& El-Kassar, A.-N. 2019. Environmental ethics, environmental performance, and competitive advantage: Role of environmental training. Technological Forecasting and Social Change, 146, 203-211. https://doi.org/10.1016/j.techfore.2019.05.032

Siswanto, D. 2019. Social Construction of Pesantren-Based Entrepreneurial Motivation. LAP LAMBERT Academic Publishing. https://www.morebooks.shop/ store/gb/book/social-construction-of-pesantren-based-entrepreneurialmotivation/isbn/978-620-0-43794-5

Siswanto, S. 2018. The Exploration of Pesantren-Based Entrepreneurship Development Strategy through Teleology Approach. El Harakah (Terakreditasi), 20(2), 191-213.

Sobirin, A. 2007. Budaya Organisasi: Pengertian, makna dan aplikasinya dalam kehidupan organisasi. UPP, STIM YKPN.

Sunuantari, M. 2012. Penerapan budaya perusahaan dalam pembentukan citra perusahaan jasa perhotelan. Journal Communication Spectrum: Capturing New Perspectives in Communication, 2(1), 43-62.

Swalhah, A. 2014. Organization culture and its role in enhancing the competitive advantage (A Case Study of Jordan Hospital). Interdisciplinary Journal of Contemporary Research in Business, 6(1), 176-185.

Syam, N. 2009. Kepemimpinan dalam Pengembangan Pondok Pesantren: Manajemen Pesantren (Halim, A., Suhartini, Arif, MC, Sunato, eds). LKiS Printing Cemerlang. 
Taliziduhu, N. 2003. Budaya Organisasi. Rineka Cipta.

Triyuwono, I. 2000. Organisasi dan akuntansi syari'ah. LKiS.

Triyuwono, I. 2006. Perspektif, metodologi, dan teori akuntansi syariah. RajaGrafindo Persada.

Triyuwono, I. S. 2001. Metafora zakat dan shari'ah enterprise theory sebagai konsep dasar dalam membentuk akuntansi syari'ah. Jurnal Akuntansi Dan Auditing Indonesia, 5(2), 131-145.

Valencia, J. C. N., Valle, R. S., \& Jiménez, D. J. 2010. Organizational culture as determinant of product innovation. European Journal of Innovation Management.

Wahyuni, M. 2013. Penerapan Akuntansi Islam dan Pelaporan Corporate Social Responsibility Perbankan Syariah. PRESTASI, 11(1A), 65-78.

Yin, R. K. (2017). Case study research and applications: Design and methods. SAGE.

Yulianto, A., \& Solikhah, B. 2016. The internal factors of Indonesian Sharia banking to predict the mudharabah deposits. Review of Integrative Business and Economics Research, 5(1), 210.

el Harakah Jurnal Budaya Islam Vol. 22 No. 2 Tahun 2020 
